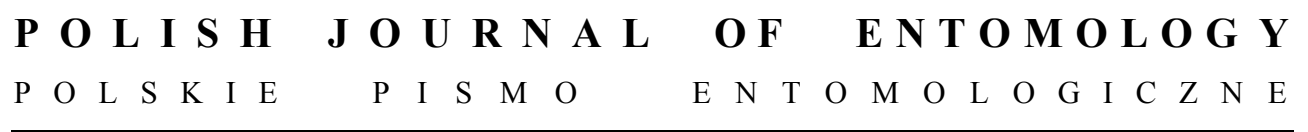

VOL. 82: $143-150$

Gdańsk

30 September 2013

DOI: $10.2478 / \mathrm{v} 10200-012-0030-\mathrm{y}$

\title{
American cockroach control assays in the municipal sewerage system of Valencia (Spain)
}

\author{
RUBÉN BUENO-MARÍ ${ }^{1}$, ALBERTO BERNUÉS-BAÑERES, \\ FRANCISCO JAVIER PERIS-FELIPO, JOSEFA MORENO-MARÍ, \\ RICARDO JIMÉNEZ-PEYDRÓ
}

Entomology and Pest Control Laboratory, Cavanilles Institute of Biodiversity and Evolutionary Biology, University of Valencia, Spain, ${ }^{1}$ e-mail: ruben.bueno@uv.es

\begin{abstract}
Several insecticides (including different active substances and formulations) were applied to sewer shafts to control Periplaneta americana (LinNAEus, 1758) populations in Valencia (eastern Spain). Results show that the best products for cockroach control were the paints (with and without insecticide), which provided an optimal reduction of $P$. americana populations for up to three months $(\mathrm{P}<0.001)$. Therefore, it is important to note that the reduction of cockroach populations as well as the persistence of the insecticide effect in sewers was similar in both types of paints. A product combining two pyrethroids (Tetramethrin and Alfacipermetrin) and piperonyl butoxide also gave excellent results with cockroach control during one month. Two organophosphate insecticides (Clorpyrifos and Diazinon) significantly reduced cockroaches for only one week. Finally, our work indicates that the Insect Growth Regulators (IGRs) we tested are not recommendable active substances for the control of $P$. americana in sewers.
\end{abstract}

KEY WORDS: environmental management, pest control, medical entomology, Periplaneta americana, insecticides, public health.

\section{INTRODUCTION}

The American cockroach Periplaneta americana (LinNAeus, 1758) is an important invasive species in several European countries of the Mediterranean region. The subtropical climate of this region provides excellent environmental conditions for the development of their populations. About twenty years ago, P. americana began to displace Blatta orientalis (LINNAEUS, 1758) in sewers, stream tunnels and drainage systems of different 
Mediterranean coastal cities, mainly in eastern and southern Spain. Nowadays, $P$. americana, commonly known in Spain as the "red cockroach", is the most frequent species in the municipal sewerage systems of these areas and has become one of the most important urban pests with high significance for public health.

Cockroaches, together with synanthropic flies, are probably the most important passive or mechanical vectors of human diseases all over the world. They are commonly associated with the transmission of a great variety of human pathogenic organisms like bacteria, viruses, fungi, protozoans and helminths (BAUMHOLTZ et al. 1997). Moreover, their accumulation gives rise to allergies as a result of human hypersensitivity to certain cuticle proteins, as well as some allergens present in excrement and other excreted substances (SoOkrung et al. 2006, Bueno Marí et al. 2009, LeE et al. 2012). Because these omnivorous insects are capable of moving from sewers to homes and commercial establishments (EADS et al. 1954), they are an obvious threat to public health. In conclusion, there is a clear need to control their populations in specific environments for sanitary and economic reasons.

In view of this, we tested the efficacy and persistence of several insecticides against cockroaches in the municipal sewerage system of Valencia (eastern Spain) during 2006 and 2007.

\section{Acknowledgements}

We would like to express our sincere thanks to the council of Valencia city as well as the pest control company commissioned for the treatments (Laboratorios Lokímica S.A.). We also thank all the research staff of the Pest Control Laboratory of the University of Valencia for their work during the tests, especially to the technician Julia Garzón for the treatment of the data. Finally, we want express our gratitude to Mario Sendra, professor of the Statistics and Operative Research Department of the University of Valencia, for his support in the statistical analysis.

\section{MATERIALS AND METHODS}

Valencia, which is situated in the east of the Iberian Peninsula $\left(39^{\circ} 28^{\prime} \mathrm{N}, 0^{\circ} 22^{\prime} \mathrm{E}\right)$, is the third largest city of Spain, with about 900000 inhabitants. The city is divided into 19 districts, and its sewer system consists of a network of about 100000 main lines under paved streets. Average summer and winter maximum temperatures are $29.6^{\circ} \mathrm{C}\left(61.0^{\circ} \mathrm{F}\right)$ and $16.1^{\circ} \mathrm{C}\left(85.3^{\circ} \mathrm{F}\right)$ respectively and winter minima do not exceed $7.0^{\circ} \mathrm{C}\left(44.6^{\circ} \mathrm{F}\right)$. Valencia receives about $454 \mathrm{~mm}$ of rainfall annually.

The few publications on cockroach control in sewerage systems were written long ago. Consequently, the methodology for this kind of study is poorly standardized. However, 
it is well known that the efficacy and persistence of insecticides in sewers depends on several factors, such as climatic conditions, amounts of organic matter, the number of cockroaches, the presence of resistant populations, the type of active matter and the kind of formulation.

The methodology of the present study was based on similar work performed in the U.S.A. (RUST et al. 1991). We selected 360 manholes situated in three districts with historically high cockroach infestation levels. They were visually inspected and all of them revealed populations of over 50 individuals of $P$. americana (adults and/or nymphs). With the aim of standardizing the data for the statistical analysis, counts were ordered from high to low, and each sewer was randomly assigned to one of nine products. We applied seven commercial insecticides with a different composition (Table 1) as well as two controls (sewers with paint not containing insecticide, and non-treated ones).

Table 1. Description of the insecticides tested.

\begin{tabular}{|c|c|c|c|}
\hline \multirow{2}{*}{ Commercial name } & \multicolumn{2}{|l|}{ Composition } & \multirow{2}{*}{ Formulation } \\
\hline & Active compound & $\%$ & \\
\hline \multirow[t]{2}{*}{ Empire $20^{\circledR}$} & Clorpyrifos & 20 & $\begin{array}{l}\text { Microencapsulated } \\
\text { liquid concentrate }\end{array}$ \\
\hline & Proprietary petroleum solvent & 10 & \\
\hline \multirow[t]{2}{*}{ Serpa D60 ${ }^{\circledR}$} & Diazinón stabilized & 60 & $\begin{array}{l}\text { Emulsifiable } \\
\text { concentrate }\end{array}$ \\
\hline & Solvent c.s.p. & 100 & \\
\hline \multirow[t]{2}{*}{ Sumilarv $10 \mathrm{EC}^{\mathbb{B}}$} & Pyriproxyfen & 10.3 & Emulsifiable liquid \\
\hline & Disolvente c.s.p. & 100 & \\
\hline \multirow[t]{2}{*}{ Diptron $\mathrm{EC} 20^{\circledR}$} & Clorpyrifos & 20 & $\begin{array}{l}\text { Emulsifiable } \\
\text { concentrate }\end{array}$ \\
\hline & Excipients and solvents c.s.p. & 100 & \\
\hline \multirow[t]{2}{*}{ Bio-blaticida $100 \mathrm{SC}^{\circledR}$} & Diflubenzuron & 12.8 & $\begin{array}{l}\text { Suspension } \\
\text { concentrate (SC) }\end{array}$ \\
\hline & Bitter substance & 0.0025 & \\
\hline \multirow[t]{4}{*}{ Ecorex alfa $^{\circledR}$} & Alphacypermethrin & 6.5 & $\begin{array}{l}\text { Microencapsulated } \\
\text { concentrate }\end{array}$ \\
\hline & Tetrametrin & 3.5 & \\
\hline & Piperonyl butoxide & 17.5 & \\
\hline & $\begin{array}{l}\text { Excipients and demineralized } \\
\text { water c.s.p. }\end{array}$ & 100 & \\
\hline \multirow[t]{4}{*}{ Inesfly $5 \mathrm{~A} \mathrm{IGR}^{\circledR}$} & Diazinon & 1.5 & Insecticide paint \\
\hline & Clorpiryfos & 1.5 & \\
\hline & Piriproxyfen & 0.063 & \\
\hline & Inert and solvent c.s.p. & 100 & \\
\hline
\end{tabular}


Depending on the type of formulation, the insecticides were applied by means of a pressured backpack for pulverization or a spray gun. All the products were applied according to the manufacturers' instructions with regard to the amount of product and applied doses. Each treatment was identified with spray-paint on the manhole cover for rapid evaluation during subsequent inspections. The effectiveness was evaluated on the basis of the population level found during inspections, carried out every day and every seven days, as well as every one, three, six and nine months after treatment. We used the Statistical Package for the Social Sciences program (SPSS 15) to apply the WILCOXON and MANN-WHITNEY tests to the data gathered.

\section{RESULTS AND DISCUSSION}

At the end of the study (nine months), the results showed that all populations had decreased to less than half of their initial levels (Table 2). However, there are certain issues that should be noted to explain several anomalous events. There were two important population decreases during the inspections carried out in July and December. Owing to the extreme climatic conditions during these two months, we measured the temperatures inside and outside the shaft during the inspections. In July we obtained average temperatures of around $35 / 28^{\circ} \mathrm{C}\left(95 / 82.4^{\circ} \mathrm{F}\right)$ inside and outside the shaft respectively. In this case the external temperature seems to be closer to the thermal optimum of $P$. americana (MURPHY et al. 1983).

Table 2. Total number of $P$. americana before and after treatment in the sewers.

\begin{tabular}{|c|c|c|c|c|c|c|c|c|}
\hline \multirow{2}{*}{ Insecticide } & \multirow{2}{*}{$\mathbf{n}$} & \multicolumn{8}{|c|}{ No. of cockroaches } \\
\cline { 3 - 9 } & & $\begin{array}{c}\text { Before } \\
\text { treatment }\end{array}$ & $\begin{array}{c}\mathbf{1} \text { d } \\
\text { June }\end{array}$ & $\begin{array}{c}\mathbf{7} \text { d } \\
\text { June }\end{array}$ & $\begin{array}{c}\mathbf{1} \text { mo } \\
\text { July }\end{array}$ & $\begin{array}{c}\mathbf{3} \text { mo } \\
\text { Sept. }\end{array}$ & $\begin{array}{c}\mathbf{6} \text { mo } \\
\text { Dec. }\end{array}$ & $\begin{array}{c}\mathbf{9} \text { mo } \\
\text { Mar. }\end{array}$ \\
\hline${\text { Empire } 20^{\circledR}}^{\circledR}$ & 40 & 3870 & 1636 & 911 & 1164 & 1458 & 653 & 1326 \\
\hline Serpa D60 $^{\circledR}$ & 40 & 4260 & 165 & 107 & 740 & 1035 & 386 & 1518 \\
\hline Sumilarv $^{\circledR}$ & 40 & 3215 & 1387 & 1335 & 917 & 1117 & 548 & 1381 \\
\hline Diptron EC20 $^{\circledR}$ & 40 & 3460 & 240 & 366 & 369 & 767 & 416 & 1320 \\
\hline Bio-Blaticida $_{100 \mathrm{SC}^{\circledR}}$ & 40 & 3100 & 1780 & 1584 & 948 & 1294 & 1163 & 1026 \\
\hline Ecorex alfa $^{\circledR}$ & 40 & 3645 & 113 & 47 & 388 & 467 & 212 & 782 \\
\hline Inesfly 5A IGR $^{\circledR}$ & 40 & 4340 & 49 & 150 & 66 & 350 & 269 & 484 \\
\hline Paint Control & 40 & 3645 & 36 & 13 & 65 & 403 & 185 & 1226 \\
\hline Control & 40 & 3804 & 3062 & 3080 & 1765 & 1899 & 1019 & 1521 \\
\hline
\end{tabular}


This fact, together with the presence of breathing holes in most manholes, explains in part the large-scale departure of cockroaches that was observed by the investigators. A high number of cockroaches has been also purposed by several authors as a likely factor to explain situations of massive departures (HAINES et al. 1955). On the other hand the opposite situation in December obtained, as the average temperature was around $16 / 12^{\circ} \mathrm{C}$ $\left(60.8 / 53.6^{\circ} \mathrm{F}\right)$ inside and outside the shaft respectively. Therefore both temperatures were negative for the cockroach cycles, with a resulting decline in reproduction. Moreover, it is probable that the cockroaches were placed in basal areas of sewers in search of microenvironments with more thermostable conditions. These migration types support investigations carried out by other authors (SCHOOF \& SIVERLY 1954, MACKIE 1969), who observed considerable movements above ground in and out of individual manholes and limited movements along lateral lines. This hypothesis could not be directly evaluated in the present research because the sewer systems of Valencia are impassable by humans, unlike those in other important Spanish cities like Barcelona or Madrid.

Although the reduction in the cockroach population is still evident at nine months, it is only significant $(P<0.001) 24$ hours after treatment (Table 3$)$. There is just a significant reduction for Bio-blaticida $100 \mathrm{SC}^{\circledR}$ at one month (July) and for Empire $20^{\circledR}$ at six months (December). To investigate whether this reduction was influenced by the same patterns that affected the control, we applied the non-parametric MANN-WHITNEY test to two independent samples (Table 4).

Table 3. Statistical significance comparing insecticides with the control.

\begin{tabular}{|c|c|c|c|c|c|c|c|}
\hline \multirow{2}{*}{ Insecticides } & \multicolumn{7}{|c|}{ Asymp. Sig. (2-tailed) ${ }^{a}$} \\
\hline & $\mathbf{0}$ & $1 \mathrm{~d}$ & $7 \mathrm{~d}$ & $1 \mathrm{~m}$ & $3 \mathrm{~m}$ & $6 \mathrm{~m}$ & $9 \mathrm{~m}$ \\
\hline Empire $20^{\circledR}-$ Control & 0.749 & $0.000 *$ & $0.000 *$ & 0.168 & 0.359 & 0.553 & 0.890 \\
\hline Serpa D60 ${ }^{\circledR}-$ Control & 0.311 & $0.000^{*}$ & $0.000^{*}$ & 0.151 & 0.113 & 0.244 & 0.805 \\
\hline Sumilarv $^{\circledR}-$ Control & 0.778 & 0.001 & 0.014 & 0.606 & 0.478 & 0.719 & 0.687 \\
\hline $\begin{array}{l}\text { Diptron EC20 } 0^{\circledR}- \\
\text { Control }\end{array}$ & 0.941 & $0.000^{*}$ & $0.000 *$ & 0.016 & 0.029 & 0.187 & 0.895 \\
\hline $\begin{array}{l}\text { Inesfly } 5 \text { A IGR }{ }^{\circledR}- \\
\text { Control }\end{array}$ & 0.390 & $0.000^{*}$ & $0.000^{*}$ & $0.000^{*}$ & $0.000^{*}$ & 0.001 & 0.010 \\
\hline $\begin{array}{l}\text { Bio-Blaticida } 100 \mathrm{SC}^{\circledR} \\
\text { - Control }\end{array}$ & 0.748 & 0.019 & 0.055 & 0.205 & 0.215 & 0.864 & 0.513 \\
\hline
\end{tabular}




\begin{tabular}{|l|c|c|c|c|c|c|c|}
\hline Ecorex alfa $^{\circledR}-$ Control & 0.368 & $0.000^{*}$ & $0.000^{*}$ & $0.000^{*}$ & 0.002 & 0.032 & 0.104 \\
\hline $\begin{array}{l}\text { Paint Control - } \\
\text { Control }\end{array}$ & 0.643 & $0.000^{*}$ & $0.000^{*}$ & $0.000^{*}$ & $0.000^{*}$ & 0.004 & 0.083 \\
\hline $\begin{array}{l}\text { Inesfly 5 A IGR } \\
\text { Paint Control }\end{array}$ & 0.206 & 0.459 & 0.043 & 0.549 & 0.627 & 0.401 & 0.583 \\
\hline
\end{tabular}

*, $P<0.001 ;$ MANN-Whitney test (SOKAL \& ROHLF 1969).

Table 4. Statistical significance comparing the activity of the products to different times.

\begin{tabular}{|c|c|c|c|c|c|c|c|c|c|c|c|c|c|}
\hline \multirow[b]{2}{*}{ Insecticide } & \multirow[b]{2}{*}{$\mathbf{n}$} & \multirow{2}{*}{$\begin{array}{c}\text { Before } \\
\text { treatment }\end{array}$} & \multicolumn{11}{|c|}{ Asymp. Sig. (2-tailed) ${ }^{a}$} \\
\hline & & & 1d-0 & $7 d-0$ & $1 \mathrm{~m}-0$ & $3 m-0$ & $6 m-0$ & $9 m-0$ & $\begin{array}{l}7 d- \\
1 d\end{array}$ & $1 \mathrm{~m}-7 \mathrm{~d}$ & $\begin{array}{l}3 \mathrm{~m}- \\
1 \mathrm{~m}\end{array}$ & $\begin{array}{l}6 \mathrm{~m}- \\
3 \mathrm{~m}\end{array}$ & $\begin{array}{l}9 m- \\
6 m\end{array}$ \\
\hline Empire $20^{\circledR}$ & 40 & 3870 & $0.000 *$ & $0.000 *$ & $0.000 *$ & $0.000 *$ & $0.000 *$ & $0.000 *$ & 0.004 & 0.264 & 0.029 & $0.000 *$ & 0.045 \\
\hline Serpa D60 ${ }^{\circledR}$ & 40 & 4260 & $0.000 *$ & $0.000 *$ & $0.000 *$ & $0.000 *$ & $0.000 *$ & $0.000 *$ & 0.039 & $0.000 *$ & 0.118 & 0.006 & $0.000^{*}$ \\
\hline Sumilarv $^{\circledR}$ & 40 & 3215 & $0.000 *$ & $0.000 *$ & $0.000 *$ & $0.000 *$ & $0.000 *$ & $0.000 *$ & 0.427 & 0.010 & 0.467 & 0.006 & 0.002 \\
\hline $\begin{array}{l}\text { Diptron } \\
\text { EC } 20^{\circledR}\end{array}$ & 40 & 3460 & $0.000 *$ & $0.000 *$ & $0.000 *$ & $0.000 *$ & $0.000 *$ & $0.000 *$ & 0.243 & 0.555 & 0.030 & 0.002 & 0.006 \\
\hline $\begin{array}{l}\text { Bio-Blaticida } \\
100 \mathrm{SC}^{\circledR}\end{array}$ & 40 & 3100 & $0.000 *$ & $0.000 *$ & $0.000 *$ & $0.000 *$ & $0.000 *$ & $0.000 *$ & 0.149 & $0.000 *$ & 0.110 & 0.025 & 0.423 \\
\hline Ecorex alfa $^{\circledR}$ & 40 & 3645 & $0.000 *$ & $0.000 *$ & $0.000 *$ & $0.000 *$ & $0.000 *$ & $0.000 *$ & 0.108 & $0.000 *$ & 0.046 & 0.001 & 0.022 \\
\hline $\begin{array}{l}\text { Inesfly } 5 \text { A } \\
\text { IGR }^{\circledR}\end{array}$ & 40 & 4340 & $0.000 *$ & $0.000 *$ & $0.000 *$ & $0.000 *$ & $0.000 *$ & $0.000 *$ & 0.538 & 0.850 & 0.015 & 0.079 & 0.256 \\
\hline Paint Control & 40 & 3645 & $0.000 *$ & $0.000^{*}$ & $0.000 *$ & $0.000 *$ & $0.000 *$ & $0.000 *$ & 0.076 & 0.034 & 0.010 & 0.026 & $0.000^{*}$ \\
\hline Control & 40 & 3804 & 0.001 & 0.024 & $0.000 *$ & $0.000 *$ & $0.000 *$ & $0.000 *$ & 0.849 & $0.000 *$ & 0.563 & $0.000 *$ & 0.416 \\
\hline
\end{tabular}

The results show that there were no significant differences between Bio-blaticida 100SC $\AA$ and Empire $20 \AA$ versus the controls in July and December respectively. The most efficient products were Inesfly 5 A IGR $\AA$ and Paint (without insecticide), offering a persistence of up to three months. Following them is Ecorex alfa ${ }^{\circledR}$ (with a month of effectivity) and Empire $20 \AA$, Serpa D60 $\AA$ and Diptron EC20®, whose persistence does not exceed one week after treatment. With respect to Sumilarv 10 EC® and Bio-blaticida $100 \mathrm{SC} \AA$ we cannot state that the observed population decrease was due to the insecticide. Therefore, we can separate the insecticides tested into four groups. In order of decreasing effectiveness we first find both types of paint (with and without insecticide). Then we find 
Ecorex alfa $\AA$. Even though resistance to pyrethroids has been widely reported (VyTHILINGAM et al. 1994), the results of Ecorex alfa® were successful. The reason may be in the type of formulation. The fact that Tetramethrin and Piperonyl butoxide are formulated as an emulsion of external aqueous phase provides a rapid effect due to its easy release of the emulsion droplets. In contrast, Alfacipermetrin due to its solid state in suspension, is released more slowly, acting as a reservoir of insecticide. The third group consists of three organophosphate insecticides: Empire $20 \AA$, Serpa D60® and Diptron EC20®. This result supports other investigations where Clorpyrifos and Diazinon exhibit similar effects of persistence (RUST et al. 1991). Finally we find Sumilarv 10 EC ${ }^{\circledR}$ and Bioblaticida $100 \mathrm{SC}{ }^{\circledR}$. These two Insect Growth Regulators (IGRs) need to be in contact with cockroaches long enough to affect their physiology and have a sufficiently great impact on their populations (BENNETT et al. 1995). From the efficiency point of view, therefore, it is vital to find a formulation that offers a high persistence of IGRs, even more so in the case of species with a long biological cycle like $P$. americana, in which nymph development can last between five and fifteen months (ROBINSON 2005).

\section{REFERENCES}

Baumholtz M., Parish L.C., Witkowski J., Nutting W. 1997. The medical importance of cockroaches. International Journal of Dermatology 36: 90-96.

BenNetT G.W., ReID B.L. 1995. Insect growth regulators. [In:] Rust K., OwENS J.M., REIERSON D.A. (eds). Understanding and controlling the German cockroach. Oxford. Michael Oxford University Press, pp.: 267-286.

Bueno Marí R., Moreno Marí J., Oltra Moscardó M.T., Jiménez Peydró R. 2009. Artrópodos con interés vectorial en la salud pública en España. Revista Española de Salud Pública 83: 201-214.

HAINES T.W., PALMER E.C. 1955. Studies of distribution and habitat of cockroaches in Southwestern Georgia, 1952-53. American Journal of Tropical Medicine and Hygiene 4: 1131-1134.

MACKIE R.A. 1969. Biology and control of cockroaches in the San Diego city sewer system. California Vector Views 16: 57-66.

MuRPhy B.F., HeAth, J.R., JAMES E. 1983. Temperature sensitivity in the prothoracic ganglion of the cockroach, Periplaneta americana, and its relationship to thermoregulation. Journal of Experimental Biology 105: 305-315.

Eads R.B., Von Zuben F.J., Bennett S.E., Walker O.L. 1954. Studies on cockroaches in a municipal sewerage system. American Journal of Tropical and Medicine Hygiene 3: 1092-1098.

LeE M.F., Song P.P., HwANG G.Y., LIN S.J., CHEN Y.H. 2012. Sensitization to per a 2 of the American cockroach correlates with more clinical severity among airway allergic patients in Taiwan. Annals of Allergy and Asthma Immunology 108: 243-248.

RoBinsON W.H. 2005. Urban insects and arachnids. Cambridge. Cambridge University Press.

Rust M.K., REIERSON D.A., HANSGE, K.H. 1991. Control of American cockroaches (Dictyoptera: Blattidae) in sewers. Journal of Medical Entomology 28: 210-213.

SCHOOF H.F., SiverLy. R.E. 1954. The occurrence and movement of Periplaneta americana (L.) within an urban sewerage system. American Journal of Tropical Medicine and Hygiene 3: 367-371. 
SoKal R.R., RoHLF F.J. 1969 Biometry. New York. W.H. Freeman and Company.

Sookrung N., Chaicumpa W., Tungtrongchitr A., Vichyanond P., Bunnag C., Ramasoota P., Tongtawe P., SAKolvaree Y., TAPChAisRi P. 2006. Periplaneta americana arginine kinase as a major cockroach allergen among Thai patients with major cockroach allergies. Environmental Health Perspectives 114: 875-880.

SPSS Inc. 2009 Statistical package for the social sciences (SPSS) Base 15.0 User's Guide. Chicago. Ed. SPSS Inc.

Vythilingam I., Sutivigit Y. 1994. Comparative susceptibility of Periplaneta americana (L) to five pyrethroid insecticides. Southeast Asian Journal of Tropical Medicine Public Health 25: 528-531.

Received: 12 August 2013

Accepted: 27 August 2013 